\title{
Three poems
}

\section{The Glimmer in the Moil}

It can't be what you think it is, spirituality.

If it were, the soft white glimmering

which blooms at night in the dim-lit waves

heaving through the kelp below Crag Point

would comprehend the ocean's dark immensity.

It gathers, it seethes in the always just before, the just before you waken, blissfully at peace, before you hear yourself say on the phone, Sorry! or out of nowhere, turning on a tap in the shower, suddenly see Christ walking along a shore.

Don't ask where it comes from, or why it's here. The moment it's thought about, even vaguely, it dies back into the moil and toil of the sea. Gone again, you say as you drowse at your desk. Gone for hours - till solitude unknows you, or prayer.

Cynics blacken, fanatics red-tide its bloom. If thoughts were plankton, and caritas oxygen, then prayer's the wave-pulse that gets it glowing. Without it, I'd never write a line, for all the kelp and sea-seethe in my psyche, the gloom.

\begin{tabular}{|c|c|c|}
\hline \multirow{5}{*}{ 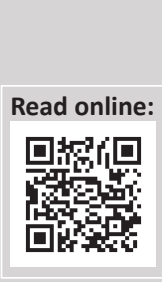 } & \multirow{5}{*}{$\begin{array}{l}\text { Scan this QR } \\
\text { code with your } \\
\text { smart phone or } \\
\text { mobile device } \\
\text { to read online. }\end{array}$} & Author: Chris Mann ${ }^{1}$ \\
\hline & & Affiliation: ${ }^{1}$ Institute for the Study of English in Africa, Rhodes University, South Africa \\
\hline & & Email: c.mann@ru.ac.za \\
\hline & & $\begin{array}{l}\text { How to cite this article: Mann, C.M., 2015, 'Three poems', Literator 36(1), Art. \#1113, } 2 \text { pages. http://dx.doi.org/10.4102/lit. } \\
\text { v36i1.1113 }\end{array}$ \\
\hline & & $\begin{array}{l}\text { Note: 'The Glimmer in the Moil' -not previously published or submitted elsewhere; 'Dancing in the Royal Hotel' - appeared } \\
\text { in a local newspaper with limited circulation in Grahamstown. (Grocott's Mail); 'The Pool of Narcissus' - an earlier version } \\
\text { was submitted to a small circulation literary magazine based in Cape Town that is not online (Prufrock). }\end{array}$ \\
\hline & & $\begin{array}{l}\text { Copyright: @ 2015. The Authors. Licensee: AOSIS OpenJournals. This work is licensed under the Creative Commons } \\
\text { Attribution License. }\end{array}$ \\
\hline
\end{tabular}




\section{Dancing in the Royal Hotel}

Was it a foxtrot or waltz? We weren't much good at it but that wasn't the point, you teetering in your heels, me awkward in a dark suit, two small-town newly-weds who'd driven miles and miles down lonely country roads to dance in the Royal Hotel on a misty Friday night.

There was hardly anyone there Do you remember the waiters in black bow-ties and tuxedos who leaned across a balustrade and watched our every move? And how the elderly pianist kept on playing Summertime and glancing over his shoulder as if longing for someone to step onto the dance floor?

You wore your party dress, still my favourite, even now, the one as black as mascara with white Botticelli flowers. Their fragrancy was you. I was watching your hands, candle-lit, slender, supple, breaking open a bread-roll when out of nowhere came love's tender, amorous gasp.

Next thing the gilded mirrors, the dark mahogany wainscot, the waiters just weren't there as haltingly we started to step then glide across the floor. I smelt your skin's perfume and felt your body's touch lightly coming and going, so joyful I'll never forget the slow swirl of that dance.

Does music dance your shades? Each time that Summertime sings in my contemplations you in your flowered dress show up across the cutlery. You're flushed, exuberant, a village where the faithful celebrate a healing vision. I'm smitten with regret to think we didn't do this more often.

Next thing, the candelabra, the lonesome at their tables, the blaze of hot white lights above the pianist returns. For we are dancing again dancing as if the energy that floats the earth, the stars, and each dead atom in its grip frees us to breathe and dream and dance love into time.

\section{The Pool of Narcissus}

He's on his hands and knees beside the pool staring at the face in the water. The din of the city below the trees, faint sounds of singing from the temple dwindle in the silence of the glade. The sun is hot on his back and shoulders, a girl is calling from a bank of flowers, he goes on staring, staring into the pool.

It's been like this for weeks, months even. Half-hidden in the trees, two figures are watching, wondering what to do. His parents, advised by his tutors, have both become, how shall I put it, discretely anxious about their boy.

Surely it wasn't like this in the past? Hadn't they better consult an oracle? Friends spoke highly of Tiresias, although quite elderly and blind.

Perhaps that blundering enthusiast Hephaestus was yet again to blame. The lame god's latest is in his hand, a marvel, a miniature bough of gold crafted in the sacred fire of his smithy. This, surely, wouldn't turn out to be as awful as the chariots and arrows, being, after all, so enlightening?

Bored, Narcissus dips it into the pool and twitches it, this way and that, above the rocks of an underworld until an open-air theatre emerges with arc on arc of crowded seats applauding a singer raising a lyre.

He stares for a while, swaying slightly, then twitches again, this way and that, rippling the placid sheen of the pool till athletes in a stadium take shape sprinting towards the winning post cheered on by throngs of spectators, a Heracles next, smeared with gore, hacking invading troops on a plain, then gliding below the lily-pads a naked nymph with long dark hair so desirable he drifts into a trance.

'Heavens above!' his mother exclaims, walking back through the dusty pines, 'what if Narcissus grows up like this, more attentive to the pool than people, unable to love anyone but himself?'

A cloud floats silently above the glade a few warm drops splash on his back as if the soft small voice of a girl was trying to get his attention. Narcissus stares on and on and on. 